\title{
Managing air quality in Suva, Fiji
}

\author{
C.F. Isley ${ }^{1}$, P.F. Nelson ${ }^{1}$ and M.P. Taylor ${ }^{1}$
}

\begin{abstract}
Increased vehicular traffic and industry, added to widespread burning of wastes, contribute to Suva's fine aerosol particle air pollution $\left(\mathrm{PM}_{2.5}\right)$; particularly aerosol black carbon (BC). As well as potential improvement of health and amenity on a local scale, better management of air quality has implications for global atmospheric warming. Diesel vehicle emissions contribute $100 \pm 30 \mathrm{t}$ of $\mathrm{PM}_{2.5}$ to Suva's air annually, including up to 75 t BC. A survey of 125 Suva households, in 2014, showed that most Suva residents burn a portion of their household waste, contributing $50 \pm 14 \mathrm{t}$ $\mathrm{PM}_{2.5}$ per year, including between $2.1 \mathrm{t}$ and $17 \mathrm{t} \mathrm{BC}$; a combustion activity that is largely unnecessary. The estimated specific forcing potential due to Suva's black carbon emissions is between 50.5 TJ and $114 \mathrm{TJ}$ annually. Emissions reductions may be achieved through various means, including alternative waste disposal practices and changes in fuel types and in fuel sulphur contents.
\end{abstract}

Key words: combustion emissions, $P M_{2.5}$, black carbon, emission estimation

\section{Introduction}

The population of Fiji is becoming increasingly urban. An estimated $53.7 \%$ of Fiji's 889,000 total population (United States Government, 2016), live in urban areas, with approximately $25 \%$ (218,000 people) living in the capital, Suva (Government of Fiji, 2012); making Suva the largest city in the tropical South Pacific Islands. Suva residents are primarily concerned about air pollution from vehicle exhaust, however they are also concerned about emissions from industry, open burning and incinerators (Government of Fiji, 2007; Isley, 2013). Lelieveld, Evans, Fnais, Glannadaki, and Pozzer (2015) report that premature mortality due to air pollution is around $50 \%$ higher in urban environments, where population and emissions are most concentrated, than in rural areas. Whilst $\mathrm{PM}_{2.5}$ concentration in Suva typically remains within the World Health Organisation guideline of $10 \mu \mathrm{g} / \mathrm{m}^{3}$ (Isley et al., 2016; World Health Organisation, 2006); aerosol BC concentrations in Suva, at $2.2 \pm 0.1 \mu \mathrm{g} / \mathrm{m}^{3}$, are higher than the average levels reported for cities in Australia, New Zealand, England and Ireland and indeed are similar to those in larger, more industrialised cites in Germany (Isley et al., 2016). Considering the levels of BC in Suva, it is likely that combustion sources will account for a significant proportion of fine aerosol PM emissions. Oil combustion produces fine PM and diesel PM are typically less than $1 \mu \mathrm{m}$ in diameter (Kittleson, F., \& Johnson, 2004; Slezakova et al., 2013). In a study of six cities in the United States of America, Laden, Schwartz, Speizer, and Dockery (2006) found that combustion particles in $\mathrm{PM}_{2.5}$ from vehicles were associated with increased mortality, whereas fine particulates derived from 
crustal sources were not associated with increased risk. Although the toxicity of particles from different sources is yet to be defined, mortality estimates based only on total $\mathrm{PM}_{2.5}$ mass 'may underestimate the total effect of PM 2.5 on mortality' p. 367 (Lelieveld et al., 2015). The International Agency for Research on Cancer (IARC, 2013) classified diesel engine exhaust as carcinogenic to humans (Group 1, see also California Air Resources Board, 2016), based on an association of diesel exhaust exposure with an increased risk for lung cancer. Black carbon also absorbs light, warming the atmosphere. Black carbon has an atmospheric lifespan of less than one year, meaning that climate impacts from emissions occur in the short-term (Bond, Zarzycki, Flanner, \& Koch, 2011). The amount of energy added to the atmosphere by $\mathrm{BC}$ emissions (specific forcing potential - SFP) can be calculated, however, this does not relate directly to temperature change, as other factors such as the earth's feedback response need to be considered (Bond et al., 2011). 'For Fiji's urban areas, vehicle emissions are amongst the most common and offensive forms of pollution' (Government of Fiji, 2007), p. 10. Over $40 \%$ of cars and $90 \%$ of other vehicles in Suva were observed to emit visible smoke (Campbell, 2004). Vehicle emissions depend on factors such as vehicle age, maintenance and fuel type (Bluett, Dey, \& Fisher, 2008; Zhang, Stedman, Bishop, Guenther, \& Beaton, 1995). In this regard, it was acknowledged in Fiji's submission to the United Nations Commission on Sustainable Development (Rogo, 2011) that second-hand vehicles of low grade and older diesel vehicles, which are common in Fiji, emit comparatively high levels of particulates. Rogo (2011) reported that emissions were exacerbated by the lower taxes on diesel fuel as compared with petrol in Fiji c.f. (Kittleson et al., 2004; Yasar, Rizwan, Bari, Kausar, \& Khan, 2013). On a volumetric and calorific basis, diesel fuel imports for automotive use in Fiji are almost double those for unleaded petrol (Fiji Bureau of Statistics, 2014). In Fiji, diesel fuel must contain no more than 500 ppm sulphur (United Nations, 2012), compared to $10 \mathrm{ppm}$ in Australia (Australian Government, 2015) and New Zealand (Mateparae, 2013); or 15ppm in the United States of America (United States Government, 2012). Penalties apply for excessively smoky vehicles in Fiji under the Land Transport Act (Parliament of the Fiji Islands, 2000) and there is some evidence of enforcement (High Court of Fiji, 2004). However, the United Nations Economic and Social Commission for Asia and the Pacific (United Nations, 2013), argues that these regulations are ineffective and 'virtually never' enforced. To encourage use of younger vehicles, with lower emissions, imports of cars, trucks and buses over four years old to Fiji were banned in 2008; although in 2009, this was downgraded to vehicles over eight years old (World Trade Organisation, 2014). Tariffs were also reduced on new buses from $27 \%$ to $5 \%$ and import excise from $15 \%$ to $5 \%$, from 2009 until 2011 (World Trade Organisation, 2014).

In addition to vehicle emissions, diesel is a major fuel used by local industries and hence derived PM forms a significant component of Suva's aerosols. Sixty-four percent of Fiji's electricity is derived from hydroelectric sources and 1\% from wind power (Fiji Electricity Authority, 2014). However, two thermal power plants (Figure 1) operate at Kinoya, in Suva city's northeast. In 2010, these plants consumed a combination of $31 \mathrm{ML}$ industrial diesel oil and 28 ML residual oil (Keruring van Elektrotechnische Materialen te Arnhem, 2012). The Fletcher Steel factory at Walu Bay in Suva's west burns a further 3.07 ML of waste oil per year (McDowall, 2005). Ships visiting the Port of Suva also use diesel to 
drive their primary and auxiliary engines. In 2010, the cost of diesel (including heavy fuel oil) and total fuel imports was equivalent to $9 \%$ and $17 \%$, respectively, of Fiji's GDP (Fiji Bureau of Statistics, 2014). The reliance on oil for electricity generation is typical of Pacific Island countries (Dornan \& Jotzo 2012; Pacific Energy Summit, 2013).

Due to the relatively small land area in Pacific Island countries, burning continues to be a convenient and practical method for waste disposal. Mataki (2011 p. 179) reported that in Honiara, the capital of the Solomon Islands, 'burning of wastes is a culturally entrenched behavior and that burning and burying of wastes seemed to be the only affordable and hygienic processes of disposal at the household level. Thaman (2003) similarly list smoke from fires for burning a diverse range of waste and open fires for cooking, along with tobacco smoke, to be the main sources of domestic air pollution in the Pacific Islands, including Fiji and that these emissions 'constitute a significant bealth hazard' (Thaman, Morrison, \& Thaman, 2003) p. 15. Burning of wastes is practiced both in urban and rural areas in Fiji, including Suva. Unregulated burning of wastes is also conducted by various industries and institutions in Suva.

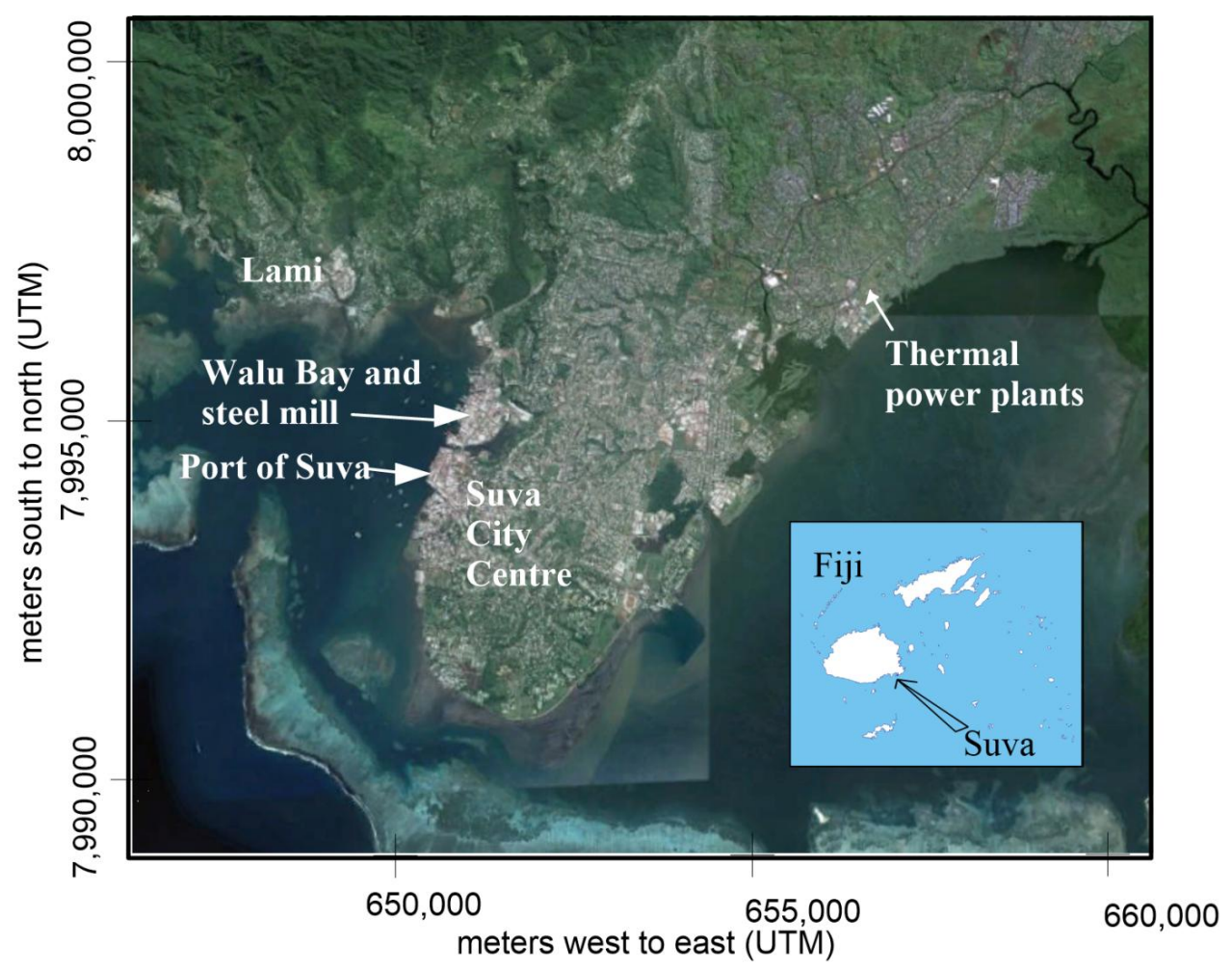

Figure 1: Location

\section{Method}

Household, industry and government combustion emissions were calculated 
using survey data and government reports. In October 2014, 125 individual Suva households were surveyed to evaluate air pollutant emissions from household waste burning activities. Results represent 25 different neighborhoods within Greater Suva, including 81 households from within the Suva City Council area. Survey questions inquired as to whether council collected waste from the household, proportion of household rubbish and garden wastes burned and what materials were removed before burning. The literature sources used to compile the emissions inventory are detailed in Table 1. Unless pollution controls were documented, it has been assumed that emissions are uncontrolled. Incinerator conditions are, in some cases, outside of the scope considered in the emission rate documentation; one incinerator reports 'lit match' p.23 as the burner (McDowall, 2005), with paper as the fuel and another is fuelled by tyres, which are not included in reported combustion volume; hence emissions are likely to be under-reported. Emissions from fossil fuel combustion were based on import and usage statistics, as shown in Table 1. For waste oil emissions, no fuel quantity was explicitly stated in McDowall (2005), this has instead been inferred from boiler capacity, assuming continuous operation. The specific forcing potential (SFP) of BC emissions from Suva is directly related to BC emission; this has been calculated, for Suva, using (Bond et al., 2011)'s values for the Oceania region (+1.03 $\pm 0.56 \mathrm{GJ} / \mathrm{g} \mathrm{BC})$.

Table 1: Data sources for fuel quantities and emission rates.

\begin{tabular}{|c|c|c|c|}
\hline $\begin{array}{l}\text { Emission } \\
\text { source }\end{array}$ & Fuel quantity & Emission factor $\mathrm{PM}_{2.5}$ & $\begin{array}{l}\text { Emission Factor BC } \\
\text { as a proportion of } \\
\mathrm{PM}_{2.5}\end{array}$ \\
\hline $\begin{array}{l}\text { Household } \\
\text { waste } \\
\text { burning }\end{array}$ & $\begin{array}{l}\text { Percentage burned } \\
\text { (survey). } \\
\text { Household waste quantity } \\
\text { by province (Government } \\
\text { of Fiji, 2012) Table } 4 . \\
\text { Waste composition } \\
\text { (Government of Fiji, 2014) } \\
\text { Table 3. }\end{array}$ & $\begin{array}{l}\text { California Air Resources } \\
\text { Board (2005); the same rate } \\
\text { applies to both household } \\
\text { waste (Table } 2.5-1 \text { ) and } \\
\text { garden waste (Table } 2.5-5 \text { ), } \\
\text { using an average of weeds, } \\
\text { field crops, orchard and } \\
\text { forest prunings. }\end{array}$ & $\begin{array}{l}4.2 \% \text { to } 33 \% \\
\text { (Chow, Watson, } \\
\text { Lowenthal, Chena, \& } \\
\text { Motallebi, 2011) } \\
\text { based on residential } \\
\text { wood combustion. }\end{array}$ \\
\hline $\begin{array}{l}\text { Medical } \\
\text { incinerators }\end{array}$ & $\begin{array}{l}\text { Incinerator specifications } \\
\text { for each hospital } \\
\text { (McDowall, 2005) }\end{array}$ & $\begin{array}{l}\text { Controlled air medical } \\
\text { waste incinerators (United } \\
\text { States Environmental } \\
\text { Protection Agency, 1995a) } \\
\text { Tables 2.3-2, 2.3-15 }\end{array}$ & $\begin{array}{l}2.4 \% \text { (Chow et al., } \\
2011)\end{array}$ \\
\hline $\begin{array}{l}\text { Other } \\
\text { incinerators }\end{array}$ & $\begin{array}{l}\text { Specifications for } \\
\text { quarantine, and } \\
\text { government office } \\
\text { incinerators (McDowall, } \\
\text { 2005) }\end{array}$ & $\begin{array}{l}\text { Controlled air solid waste } \\
\text { incinerators (United States } \\
\text { Environmental Protection } \\
\text { Agency, 1995b) Table 2.1-9 }\end{array}$ & $\begin{array}{l}2.4 \% \text { (Chow et al., } \\
2011)\end{array}$ \\
\hline $\begin{array}{l}\text { Industrial } \\
\text { diesel and } \\
\text { residual oil } \\
\text { for } \\
\text { electricity } \\
\text { generation }\end{array}$ & $\begin{array}{l}\text { Generator specifications } \\
\text { by location (Keruring van } \\
\text { Elektrotechnische } \\
\text { Materialen te Arnhem, } \\
\text { 2012) }\end{array}$ & $\begin{array}{l}\text { National pollutant } \\
\text { inventory (NPI) manual for } \\
\text { boilers (Australian } \\
\text { Government, 2011) Table } \\
28 \text { (industrial diesel), Table } \\
26 \text { (residual oil) }\end{array}$ & $\begin{array}{l}3 \% \text { to } 13.6 \% \\
\text { Chow et al. (2011), } \\
77 \% \text { (United States } \\
\text { Environmental } \\
\text { Protection Agency, } \\
2012 \text { ) }\end{array}$ \\
\hline
\end{tabular}




\begin{tabular}{|c|c|c|c|}
\hline $\begin{array}{l}\text { Waste oil } \\
\text { combustion } \\
\text { by industry }\end{array}$ & $\begin{array}{l}\text { Furnace details for specific } \\
\text { industries (McDowall, } \\
\text { 2005; Secratatiat of the } \\
\text { Pacific Environment } \\
\text { Programme, 2011); fuel } \\
\text { conversion factors (United } \\
\text { Kingdom Government, } \\
\text { 2008). Assumed boiler } \\
\text { operates continuously. }\end{array}$ & $\begin{array}{l}\text { NPI boilers, (Australian } \\
\text { Government, 2011) Table } \\
30\end{array}$ & $\begin{array}{l}\text { 77\% (United States } \\
\text { Environmental } \\
\text { Protection Agency, } \\
\text { 2012) }\end{array}$ \\
\hline $\begin{array}{l}\text { Industrial } \\
\text { diesel } \\
\text { imports not } \\
\text { otherwise } \\
\text { allocated }\end{array}$ & $\begin{array}{l}\text { Fiji Bureau of Statistics } \\
\text { (2014); assumed to be } \\
\text { distributed according to } \\
\text { the population density }\end{array}$ & $\begin{array}{l}\text { NPI boilers (Australian } \\
\text { Government, 2011) Table } \\
28\end{array}$ & $\begin{array}{l}77 \% \text { (United States } \\
\text { Environmental } \\
\text { Protection Agency, } \\
\text { 2012) }\end{array}$ \\
\hline $\begin{array}{l}\text { Combustion } \\
\text { of fuel by } \\
\text { vehicles }\end{array}$ & $\begin{array}{l}\text { Fiji Bureau of Statistics } \\
\text { (2012) Automotive diesel } \\
\text { usage was assumed to be } \\
\text { distributed according to } \\
\text { vehicle registrations (Fiji } \\
\text { Bureau of Statistics, 2012) } \\
\text { and by population; light } \\
\text { goods vehicles (LGV) } 32 \\
\% \text {, medium goods vehicle } \\
\text { (MGV) } 32 \% \text {, heavy goods } \\
\text { vehicles (HGV) } 31 \% \\
\text { (assuming half of these are } \\
\text { very HGV) and buses } 5 \% \text {. }\end{array}$ & $\begin{array}{l}\text { NPI combustion engines } \\
\text { (Australian Government, } \\
\text { 2008); using Table } 10 \\
\text { unleaded petrol (ULP) and } \\
\text { Table } 14 \text { for ULP with } 10 \\
\% \text { biofuel (same emission } \\
\text { rate as ULP); diesel LGV } \\
\text { (Table 15: } 2.34 \mathrm{~g} / \mathrm{L} \text { ), MGV } \\
\text { (Table 20: } 2.25 \mathrm{~g} / \mathrm{L}) \text {, HGV } \\
\text { (Table } 21: 1.73 \mathrm{~g} / \mathrm{L}), \text { very } \\
\text { HGV (Table } 22: 1.12 \mathrm{~g} / \mathrm{L}) \\
\text { and bus (Table } 23: 1.12 \\
\text { g/L). These assume } 10 \text { ppm } \\
\text { sulphur content, adjustment } \\
\text { of + } 32 \% \text { (Boulter \& } \\
\text { Latham, } 2009 \text { ) for Fijian } \\
\text { vehicle fuels, which contain } \\
\text { up to } 500 \text { ppm (United } \\
\text { Nations, } 2012 \text { ) }\end{array}$ & $\begin{array}{l}\text { Lower estimates } \\
\text { listed are from Chow } \\
\text { (2011): } 5.9 \% \text { for } \\
\text { ULP, } 33 \% \text { HGV } \\
\text { diesel and } 62 \% \\
\text { LGV diesel; higher } \\
\text { estimate of } 75 \% \text { is } \\
\text { from USEPA (2012) }\end{array}$ \\
\hline $\begin{array}{l}\text { Liquefied } \\
\text { petroleum } \\
\text { gas (LPG) }\end{array}$ & $\begin{array}{l}\text { Fiji Bureau of Statistics } \\
(2012)\end{array}$ & Haneke (2001) Table 2 & $\begin{array}{l}5.9 \% \text { to } 37 \% \\
\text { (Chow et al., 2011) }\end{array}$ \\
\hline $\begin{array}{l}\text { Kerosene } \\
\text { burning }\end{array}$ & $\begin{array}{l}\text { Fiji Bureau of Statistics } \\
\text { (2012) }\end{array}$ & $\begin{array}{l}\text { Based on wick stoves (Lam, } \\
\text { Smith, Gauthier, \& Bates, } \\
\text { 2012), Table } 5\end{array}$ & $\begin{array}{l}80 \% \text { (Lam et al., } \\
2012)\end{array}$ \\
\hline $\begin{array}{l}\text { Household } \\
\text { wood } \\
\text { burning }\end{array}$ & $\begin{array}{l}\text { Fuelwood consumption } \\
0.05 \mathrm{~m}^{3} \text { per capita (Brown, } \\
\text { 1997) Table } 15 \text {, biomass } \\
\text { density } 0.57 \mathrm{t} / \mathrm{m}^{3} \text { (Food } \\
\text { and Agriculture } \\
\text { Organization, 2016); } \\
\text { proportion of urban } \\
\text { households cooking with } \\
\text { biomass (survey). }\end{array}$ & $\begin{array}{l}\text { California Air Resources } \\
\text { Board (2005); as per garden } \\
\text { waste above. }\end{array}$ & $\begin{array}{l}4.2 \% \text { to } 33 \% \\
\text { (Chow et al., 2011) }\end{array}$ \\
\hline
\end{tabular}


This study has focused on activities that occur within Suva and have potential for emissions reduction on a local scale. Emissions from shipping and aviation have not been included, although some shipping emissions may have been counted within industrial diesel calculations. Similarly, agricultural burning, which occurs away from Suva, has not been included. Emissions from property fires and cremation have not been calculated. Only primary PM emissions have been considered in this study; excluding secondary particles, formed in the atmosphere from emissions of $\mathrm{SO}_{2}$ and $\mathrm{NO}_{2}$. Where no error values were provided, European Environmental Agency (Pulles \& Kuenen, 2009) methods for determining uncertainty in emissions calculations have been followed; these provide uncertainty calculations for comparing statistical data collected in different years as well as using emissions factors derived from various sources.

\section{Results and Discussion}

Survey results from October 2014 show that although $87.9 \%$ of respondents have waste collection by council, more than half of Suva residents burn a portion of their household and garden wastes. The majority of households were able to estimate what proportion of waste they burn (Table 2), however $8.1 \%$ of households were not sure of the proportion burned. Overall, $21.0 \pm 3.8 \%$ of Suva's household waste and $34.5 \pm 6.2$ $\%$ of garden wastes were burned. Suva council collected $109 \mathrm{~kg}$ waste per person in 2011 and estimated that $20 \%$ of household waste remained uncollected (Government of Fiji, 2012). This waste stream is typically composed of $36.9 \%$ kitchen waste with other major components being 21.4\% garden waste (grass and wood), $15.3 \%$ paper and 10.3\% plastic (Government of Fiji, 2014). The composition and the burning of wastes by households is typical of wastes across the Pacific Islands (Mataki, 2011), where variation of wastes across seasons and housing estates in differing socio-economic areas is not significant (Yao, 2008). Around half of households that burn waste remove metals and glass beforehand (Table 2). Considering these waste-stream proportions, the rate of waste burning in greater Suva is equivalent to each resident burning $27.7 \pm 5.0 \mathrm{~kg}$ of household waste and $13.7 \pm 2.4 \mathrm{~kg}$ of garden waste every year. This contributes $50 \pm 14$ $\mathrm{t}$ of $\mathrm{PM}_{2.5}$ into Suva's air every year, with between $2.1 \mathrm{t}$ and $17 \mathrm{t}$ of this being BC. Assuming that other areas with waste services exhibit similar burning behavior to Suva and using McDowall's (2005) rural waste estimates, household waste burning across Fiji contributes $210 \pm 90$ t $\mathrm{PM}_{2.5}$ annually, with up to $69 \mathrm{t} \mathrm{BC}$. 
Table 2: Summary of 2014 survey results for waste burning in Suva

\begin{tabular}{|l|l|l|l|l|l|}
\hline $\begin{array}{l}\text { Proportion } \\
\text { burned }(\%)\end{array}$ & $\begin{array}{l}\text { Household } \\
\text { waste }(\%)\end{array}$ & $\begin{array}{l}\text { Garden } \\
\text { waste } \\
(\%)\end{array}$ & & $\begin{array}{l}\text { Waste } \\
\text { material }\end{array}$ & $\begin{array}{l}\text { Households removing material before } \\
\text { burning as a subset of those that burn } \\
\text { waste }(\%)\end{array}$ \\
\hline 0 & 37.9 & 33.9 & & &
\end{tabular}

Considering that for Suva, most houses are serviced by waste collection, waste burning emissions could be greatly reduced. Only $21 \%$ of respondents without waste collection indicated that they burn half or more of their household or garden waste. Alternative waste disposal methods practiced by communities not serviced by council waste collection in Suva include rental of skip bins on a community level, composting, feeding kitchen waste to animals, reuse of materials and local dumping of wastes. Metal and reusable glass bottles can be exchanged for payment in Suva. The average proportion of waste burned by those without waste services is $45 \pm 2 \%$ of household waste and $43 \pm$ $11 \%$ of garden waste. Assuming that households in Suva without a waste service will require to burn $50 \%$ of their waste, it is still possible to reduce the annual $\mathrm{PM}_{2.5}$ emission from waste burning, in Suva, by $47 \pm 12 \mathrm{t}$, including up to $16 \mathrm{t} \mathrm{BC}$.

Using reported combustion volumes, incinerators contribute a combined annual total of $920 \pm 230 \mathrm{~kg} \mathrm{PM}_{2.5}$ to Suva's air, including $22 \mathrm{~kg} \mathrm{BC}$. For Fiji, the annual emission is 2.3 $\pm 0.6 \mathrm{t} \mathrm{PM}_{2.5}$, including $55 \mathrm{~kg} \mathrm{BC}$. The majority of incinerators are burning quarantine or medical wastes, hence finding an alternative hygienic disposal method is difficult. If alternate waste disposal were practiced for incinerators burning only paper (McDowall, 2005), an emission reduction of $93 \pm 23 \mathrm{~kg} \mathrm{PM}_{2.5}$ per year could be achieved.

Households in Suva also burn kerosene or biomass fuel for cooking purposes. The October 2014 household survey reported that $28 \%$ of Suva City Council households and $36 \%$ of Greater Suva households surveyed used kerosene for cooking food. Many of these households use a combination of fuels, also including gas or electricity. The proportion of households burning kerosene for lighting were $17 \%$ and $21 \%$ respectively for Suva Council and the Greater Suva area. Kerosene represents an annual $\mathrm{PM}_{2.5}$ emission of $420 \pm 240 \mathrm{~kg}$, with $33 \pm 19 \mathrm{~kg} \mathrm{BC}$. While this is a small contribution to total $\mathrm{PM}_{2.5}$ emissions, exposure is enhanced as indoor emissions are not readily dispersed. $\mathrm{PM}_{2.5}$ emissions from LPG combustion are around half those for kerosene, at $170 \pm 40 \mathrm{~kg}$ annually for Suva and $730 \pm 180 \mathrm{~kg}$ for Fiji, with around one-tenth the BC emission of kerosene. Considering that $80 \pm 7 \%$ of Suva residents use LPG for cooking, this demonstrates that LPG provides a lower-emission alternative to kerosene. Likewise, 
wood was used by $20 \%$ of households, for cooking food, in Suva City Council and Greater Suva and coconut fiber was used by $5 \%$. Household wood burning for cooking contributes significantly to Suva's $\mathrm{PM}_{2.5}$ with $13.4 \pm 4.70$ t $\mathrm{PM}_{2.5}$ and up to $4.43 \mathrm{t} \mathrm{BC}$ emitted to Suva's air annually, with $203 \pm 71 \mathrm{t} \mathrm{PM}_{2.5}$ for all of Fiji. Contributions from diesel-fueled vehicles are far greater than for petrol vehicles (Table 3 ) and indeed are estimated to form the largest contribution to Suva's $\mathrm{PM}_{2.5}$ and BC. On the whole, using fuel import volumes, vehicle emissions contribute $100 \pm 30 \mathrm{t}$ of $\mathrm{PM}_{2.5}$ annually for Suva, including up to 75 t BC. For Fiji, this becomes $410 \pm 100$ t $\mathrm{PM}_{2.5}$ including 310 t BC annually. Driving speeds, road gradients and vehicle maintenance all affect emissions (Grote, Williams, Preston, \& Kemp, 2016); these factors are unable to be fully accounted for in these emissions calculations, which must therefore be considered as estimates. Boulter \& Latham (2009) demonstrated that sulphur reduction from $307 \mathrm{ppm}$ to $208 \mathrm{ppm}$ (8.8 \% sulphur reduction) in diesel fuel resulted in 10.5\% decrease in $\mathrm{PM}_{2.5}$ emissions. For Suva, where sulphur may constitute up to $500 \mathrm{ppm}$ (United Nations, 2012), it is expected that a $10 \%$ decrease in sulphur content would reduce $\mathrm{PM}_{2.5}$ emissions by approximately $10 \%$. This equates to a reduction of approximately $10 \mathrm{t}$ per year $\mathrm{PM}_{2.5}$, including up to $7.5 \mathrm{t} \mathrm{BC}$ for Suva. Reduction of sulphur content to $10 \mathrm{ppm}$ is expected to give a $32 \%$ emission reduction $\left(32 \mathrm{t} \mathrm{PM}_{2.5}\right.$ annually based on Boulter \& Latham 2009). Regulation of vehicle maintenance may bring additional emission reductions. Low sulphur fuels are more expensive and vehicle maintenance checks require personnel and equipment, forming an economic barrier to reduction of emissions. Further investigation is required into the cost of changing fuel composition and the comparative health costs from exposure to diesel combustion emissions.

Table 3: Emission from combustion activities in Suva and Fiji

\begin{tabular}{|l|l|l|l|l|}
\hline Source & $\begin{array}{l}\text { Annual quantity } \\
\text { Suva } \\
\text { (Fiji) }\end{array}$ & $\begin{array}{l}\mathrm{PM}_{2.5} \text { Emission } \\
\text { ratei }\end{array}$ & $\begin{array}{l}\mathrm{PM}_{2.5} \text { emission } \mathrm{t} / \mathrm{yr} \\
\text { Suva } \\
\text { (Fiji) }\end{array}$ & $\begin{array}{l}\text { BC emission } \\
\text { Suva } \\
\text { (t/yr) }\end{array}$ \\
\hline $\begin{array}{l}\text { Electricity } \\
\text { generation } \\
\text { industrial diesel } \\
\text { IDO) }\end{array}$ & $\begin{array}{l}31.0 \pm 1.6 \mathrm{ML} \\
(58.2 \pm 2.9 \mathrm{ML})\end{array}$ & $\begin{array}{l}25.1 \pm 5.0 \\
\mathrm{~kg} / \mathrm{ML}\end{array}$ & $\begin{array}{l}0.78 \pm 0.2 \\
1.50 \pm 0.4\end{array}$ & 0.024 to 0.60 \\
\hline $\begin{array}{l}\text { Electricity } \\
\text { generation residual } \\
\text { oil }\end{array}$ & $\begin{array}{l}28.3 \pm 1.4 \mathrm{ML} \\
(28.3 \pm 1.4 \mathrm{ML})\end{array}$ & $\begin{array}{l}0.108 \pm 0.022 \\
\mathrm{t} / \mathrm{ML}\end{array}$ & $\begin{array}{l}3.1 \pm 0.6 \\
(3.2 \pm 0.8)\end{array}$ & 0.092 to 2.4 \\
\hline $\begin{array}{l}\text { Industrial waste oil } \\
\text { furnaces }\end{array}$ & $\begin{array}{l}3.07 \pm 0.15 \mathrm{ML} \\
(3.07 \pm 0.15 \\
\mathrm{ML})\end{array}$ & $\begin{array}{l}3.26 \pm 0.72 \\
\mathrm{t} / \mathrm{ML}\end{array}$ & $\begin{array}{l}10.0 \pm 2.5 \\
(10.0 \pm 2.5)\end{array}$ & $7.7 \pm 1.92$ \\
\hline $\begin{array}{l}\text { IDO industry other } \\
(162 \pm \pm 2.0 \mathrm{ML}\end{array}$ & $\begin{array}{l}25.1 \pm 5.0 \\
\mathrm{~kg} / \mathrm{ML}\end{array}$ & $\begin{array}{l}1.0 \pm 0.3 \\
(4.1 \pm 1.0)\end{array}$ & $0.80 \pm 0.28$ \\
\hline $\begin{array}{l}\text { Incinerators } \\
\text { medical waste }\end{array}$ & $\begin{array}{l}800 \pm 40 \mathrm{t} \\
(1040 \pm 50 \mathrm{t})\end{array}$ & $\begin{array}{l}1.01 \pm 0.20 \\
\mathrm{~kg} / \mathrm{t}\end{array}$ & $\begin{array}{l}0.81 \pm 0.2 \\
(1.1 \pm 0.3)\end{array}$ & $0.029 \pm 0.001$ \\
\hline $\begin{array}{l}\text { Incinerators other } \\
145 \pm 7 \mathrm{t} \\
(1610 \pm 80 \mathrm{t})\end{array}$ & $\begin{array}{l}0.75 \pm 0.15 \\
\mathrm{~kg} / \mathrm{t}\end{array}$ & $\begin{array}{l}0.11 \pm 0.03 \\
(1.2 \pm 0.3)\end{array}$ & $\begin{array}{l}0.0012 \pm \\
0.0004\end{array}$ \\
\hline
\end{tabular}




\begin{tabular}{|l|c|c|c|c|}
\hline Vehicles ULP & $\begin{array}{c}24.9 \pm 1.3 \mathrm{ML} \\
(102 \pm 5 \mathrm{ML})\end{array}$ & $62 \pm 12 \mathrm{~g} / \mathrm{ML}$ & $\begin{array}{c}0.0015 \pm 0.004 \\
(0.0063 \pm 0.016)\end{array}$ & $\begin{array}{c}0.000091 \pm \\
0.000032\end{array}$ \\
\hline Vehicles diesel & $\begin{array}{c}4.18 \pm 0.21 \mathrm{x} \\
10^{7} \mathrm{~L} \\
(1.71 \pm 0.05 \mathrm{x} \\
\left.10^{8} \mathrm{~L}\right)\end{array}$ & $\begin{array}{c}2.40 \pm 0.48 \\
\mathrm{~g} / \mathrm{L}\end{array}$ & $\begin{array}{c}100 \pm 30 \\
(410 \pm 100)\end{array}$ & 40 to 75 \\
\hline LPG & $\begin{array}{c}4.37 \pm 0.21 \mathrm{kt} \\
(18.2 \pm 0.9 \mathrm{kt})\end{array}$ & $39.9 \pm 8.0 \mathrm{~g} / \mathrm{t}$ & $\begin{array}{c}0.17 \pm 0.04 \\
(0.73 \pm 0.18)\end{array}$ & $\begin{array}{c}0.0010 \text { to } \\
0.0064\end{array}$ \\
\hline $\begin{array}{l}\text { Household waste } \\
\text { burning }\end{array}$ & $\begin{array}{c}6270 \pm 1200 \mathrm{t} \\
(26.2 \pm 4.7 \mathrm{kt})\end{array}$ & $8.0 \pm 1.2 \mathrm{~kg} / \mathrm{t}$ & $\begin{array}{c}50 \pm 14 \\
210 \pm 90\end{array}$ & 2.1 to 17 \\
\hline $\begin{array}{l}\text { Household wood } \\
\text { burning }\end{array}$ & $\begin{array}{c}1.68 \pm 0.37 \mathrm{kt} \\
25.3 \pm 5.0 \mathrm{kt}\end{array}$ & $8.0 \pm 1.2 \mathrm{~kg} / \mathrm{t}$ & $\begin{array}{c}13.4 \pm 4.70 \\
203 \pm 71\end{array}$ & 0.56 to 4.43 \\
\hline Kerosene & $\begin{array}{c}1.00 \pm 0.05 \mathrm{ML} \\
(4.00 \pm 0.20 \\
\mathrm{ML})\end{array}$ & $42 \pm 24 \mathrm{~g} / \mathrm{L}$ & $\begin{array}{c}0.42 \pm 0.24 \\
(0.17 \pm 0.10)\end{array}$ & $0.33 \pm 0.19$ \\
\hline TOTAL & & $\begin{array}{c}180 \pm 53 \\
845 \pm 267\end{array}$ & 49 to 111 \\
\hline
\end{tabular}

[i]. (Fiji Bureau of Statistics, 2012; Government of Fiji, 2012, 2014; Keruring van Elektrotechnische Materialen te Arnhem, 2012; McDowall, 2005; Pulles \& Kuenen, 2009; Secratatiat of the Pacific Environment Programme, 2011) [ii]. (Australian Government, 2008, 2011; Boulter \& Latham, 2009; California Air Resources Board, 2005; Haneke, 2001; United Nations, 2012; United States Environmental Protection Agency, 1995a, 1995b). [iii] (Bond et al., 2004)

Industrial diesel emissions contribute a combined total of about $15 \mathrm{t}$ of $\mathrm{PM}_{2.5}$ to Suva's air annually, including approximately 8.5 t BC. Waste oil emission rates assume a sulphur content between $0.01 \%$ and $0.2 \%$ (Australian Government, 2011); if sulphur contents are outside of this range, or emissions controls are present, the emission may vary from that reported here. A change from the use of residual oil to industrial diesel (IDO) would bring a reduction of around $2.4 \mathrm{t} \mathrm{PM}_{2.5}$ per year for Suva. Changing from use of waste oil to IDO could theoretically reduce emissions by around $9.9 \mathrm{t}$ annually. Air quality is not the only consideration here. Combustion of waste oil by industry prevents disposal of these oils into waterways, where they can damage aquatic ecosystems and human health. If not combusted to provide benefit for industry, it is also possible, even likely, that waste oils would be combusted simply as a disposal technique. Likewise, the increased cost of IDO over residual oil, used for electricity generation, would increase the cost of production and ultimately the cost to electricity consumers. A variety of other emissions controls are available for industrial combustion, including pre-treatment of oils prior to combustion. The investigation of suitable emission control techniques and the economic, health and environmental consequences of using different fuels are necessary.

Diesel vehicles were calculated as the largest contributor to Suva's $\mathrm{PM}_{2.5}$ and BC, followed by household waste burning, household wood burning, industrial waste oil combustion and residual oil burning. Similarly, transport emissions and residential use of biofuels are amongst the largest contributors to BC in many areas of the world (Bond, 2007). Not all sources contribute equally to exposure and health impact. Industrial emissions are usually emitted via stacks, often at high temperature, where thermal buoyancy and dispersion of pollutants results in ground level concentrations that are 
much lower than emitted concentrations. For household burning of wastes and vehicle emissions, emission points are much lower to the ground and nearby individuals are exposed to a greater proportion of the original emitted concentration. Emissions from cooking, which occur within the confines of a dwelling, have greater exposure potential. Unlike waste burning and vehicle emissions, industrial emissions tend to occur away from heavily populated residential areas, also reducing exposure. These spatial considerations do not apply to the specific forcing potential of the emissions, which remain constant.

The annual SFP of Suva's black carbon emissions is between 50.5 TJ and 114 TJ. Being directly proportional to $\mathrm{BC}$ emissions, this SFP is predominately due to diesel vehicle emissions. Suva's per-capita BC emission is $0.22 \mathrm{~kg}$ to $0.51 \mathrm{~kg}$ per year. This is less than or similar to per-capita emissions from South Asia, Western Africa or the Middle East and about half that of the USA, Oceania and Eastern Europe (Bond, 2007). This relatively low per-capita emission does not explain the relatively high $\mathrm{BC}$ concentrations measured in Suva and further investigation of BC contributions is required. Shipping and agricultural burning contributions require consideration as well as the formation of secondary PM particles. Other pollutants; carbon dioxide, methane, nitrous oxide and fluorinated gases, that contribute to climate change, have not been considered in this study. Being a nation composed of 106 inhabited islands, Fiji has incentive to reduce BC emissions, which contribute to global warming and change in sea levels.

\section{Conclusion}

The greatest reductions in $\mathrm{PM}_{2.5}$ and $\mathrm{BC}$ emissions would be gained from changes in diesel vehicle emissions. The second highest contributor is household burning of wastes. Apart from those without waste collection services, this is a preventable emission and could reduce $\mathrm{PM}_{2.5}$ in Suva's residential areas by $47 \pm 8 \mathrm{t}$ annually. The economic and health basis for reducing emissions warrants further exploration, along with further data collection to refine this emissions inventory.

\section{References:}

Australian Government. (2008). Emission estimation technique manual for combustion engines v3.0. Retrieved from http://www.npi.gov.au/

Australian Government. (2011). National pollutant inventory emission estimation technique manual for combustion in boilers. Retrieved from http://www.npi.gov.au/system/files/resources/3ae8d11b-1ece-ff74-5dc5cbc7d27a4aa6/files/boilers.pdf

Australian Government. (2015). Diesel fuel quality standard. Retrieved from www.environment.gov.au/topics/environment-protection/fuel-quality/standards/diesel.

Bluett, J., Dey, K., \& Fisher, G. (2008). Assessing vehicle air pollution emissions. Retrieved from http://www.environment.gov.au/system/files/resources/73c55f4c-9b4f-4ae8-a09ed089a703d29a/files/vehicle-pollution.pdf.

Bond, T. C. (2007). Can warming particles enter global climate discussions? Environmental Research Letters, 2(4), 045030.

Bond, T. C., Streets, D. G., Yarber, K. F., Nelson, S. M., Woo, J.-H., \& Klimont, Z. (2004). A technologybased global inventory of black and organic carbon emissions from combustion. Jounal of Geophysical Research, 109(D14203), 43. doi:10.1029/2003JD003697 
Bond, T. C., Zarzycki, C., Flanner, M. G., \& Koch, D. M. (2011). Quantifying immediate radiative forcing by black carbon and organic matter with the Specific Forcing Pulse. Atmos. Chem. Phys., 11, 15051525. doi:10.5194/acp-11-1505-201

Boulter, P. G., \& Latham, S. (2009). A review of the effects of fuel properties on road vebicle emissions. (PPR358). TRL Retrieved from https://www.gov.uk/government/uploads/system/...data/.../report-5.pdf.

Brown, C. (1997). Asia-Pacific forestry sector outlook study: Regional study - the South Pacific. (Working Paper No: APFSOS/WP/01). Bangkok: United Nations Forestry Policy and Planning Division Retrieved from ftp://ftp.fao.org/docrep/fao/003/W4354E/W4354E00.pdf.

California Air Resources Board. (2005). Agricultural burning and other burning methodology. Retrieved from www.arb.ca.gov/ei/areasrc/fullpdf/full7-17.pdf.

California Air Resources Board. (2016). Diesel Exhaust and Health. Retrieved from http://www.arb.ca.gov/research/diesel/diesel-health.htm.

Campbell, A. (2004). Road safety reform and safety improvement. (TA No. 2850-FIJ).

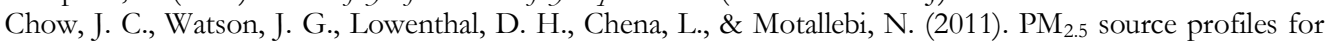
black and organic carbon emission inventories. Atmospheric Environment(45), 5407-5414. doi:10.1016/j.atmosenv.2011.07.011

Dornan, M. \& Jotzo, F. (2012). Fiji can't function without oil: cheap renewables could reduce the risk. The Conversation, February 16th 2012.

Fiji Bureau of Statistics. (2012). Estimated annual consumption of selected commodities per head of population. Retrieved from http://www.statsfiji.gov.fj/

Fiji Bureau of Statistics. (2014). Fiji Facts and Figures 2011. Retrieved from http://www.statsfiji.gov.fj/.

Fiji Electricity Authority. (2014). Annual Report 2012. Retrieved from < $\underline{\text { http://www.fea.com.fj/wp- }}$ content/uploads/2014/02/FEA-ANNUAL-REPORT-2012.pdf>.

Food and Agriculture Organization. (2016). Estimating biomass and biomass change in tropical forests. Retrieved from http://www.fao.org/docrep/w4095e/w4095e06.htm.

Government of Fiji. (2007). National Air Pollution Control Strategy. Suva, Fiji Retrieved from http://www.environment.gov.fj/national-air-pollution-control-strategy/.

Government of Fiji. (2012). Fiji solid waste management strategy 2011 - 2014. Retrieved from https://doefiij.files.wordpress.com/2013/10/nswms 2011 -2014.pdf.

Government of Fiji. (2014). Report on feasibility of resources and sites for waste-to-energy power generation in fiji. Retrieved from http://prdrse4all.spc.int/production/system/files/141003 final report on w2e feasibility of re sources sites.pdf.

Grote, M., Williams, I., Preston, J., \& Kemp, S. (2016). Including congestion effects in urban road traffic CO2 emissions modelling: Do Local Government Authorities have the right options? Transportation Research Part D: Transport and Environment, 43, 95 - 106.

Haneke, B. H. (2001). A national methodology and emission inventory for residential fuel combustion. NC 27709: PES, Inc. Retrieved from https://www3.epa.gov/ttnchie1/conference/ei12/area/haneke.pdf.

Suresh Chandra v Land Transport Authority, High Court of Fiji, Criminal Appeal, HAA024 of 2004S Sess (2004).

IARC. (2013). IARC: Outdoor air pollution a leading environmental cause of cancer deaths [Press release]. Retrieved from http://www.iarc.fr/en/media-centre/iarcnews/pdf/pr221 E.pdf

Isley, C. F. (2013). Public perceptions of air pollution in Suva. . https://sites.google.com/site/suvaairquality/perceptions-survey

Isley, C. F., Nelson, P. F., Taylor, M. P., Mani, F., Maata, M., Cohen, D. D., Atanacio, A. \& Stelcer, E. (2016). PM 2.5 and aerosol black carbon in Suva, Fiji. in preparation.

Keruring van Elektrotechnische Materialen te Arnhem. (2012). Quantification of the power system energy losses in South Pacific utilites. Retrieved from http://www.ppa.org.fi/wp-content/uploads/2013/04/FEAReport.pdf.

Kittleson, D. B., F., W. W., \& Johnson, J. P. (2004). Nanoparticle emissions on Minnesota highways. Atmos. Environ, 38(1), 9-19.

Laden, F., Schwartz, J., Speizer, F. E., \& Dockery, D. W. (2006). Reduction in fine particulate air pollution and mortality: Extended follow-up of the Harvard Six Cities study. Am J Respir Crit Care Med, 173(6), 667-672. doi:10.1164/rccm.200503-443OC 
Lam, N. L., Smith, K. R., Gauthier, A., \& Bates, M. N. (2012). Kerosene: A review of household uses and their hazards in low- and middle-income countries. J Toxicon Environ Health, 15(6), 396-432. doi:10.1080/10937404.2012.710134

Lelieveld, J., Evans, J. S., Fnais, M., Glannadaki, D., \& Pozzer, A. (2015). The contribution of outdoor air pollution sources to premature mortality on a global scale. Nature, 525, 367 - 371. doi:10.1038/nature15371

Mataki, M. (2011). A critical assessment of the paradigms for solid waste management in Pacific Island countries. (PhD), Murdoch University.

Mateparae, J. (2013). Engine Fuel Specifications Regulations 2011. (SR 2011/352). Wellington Retrieved from http://www.legislation.govt.nz/regulation/public/2011/0352/latest/whole.html.

McDowall, R. (2005). Enabling Activities for the Development of a National Plan for Implementation of the Stockbolm Convention on POPs. Retrieved from http://www.mcdowall.ac.nz/Site/UNEPPublications files/Fiji.pdf

Pacific Energy Summit. (2013, 24-26 March 2013). Energy needs in the Pacific. Paper presented at the Energy needs in the Pacific, Auckland, NZ.

Parliament of the Fiji Islands, Land Transport Act, 47 \& 106(3) \ Visible smoke infringement (2000).

Pulles, T., \& Kuenen, J. (2009). Retrieved from https: $/ /$ www.google.com.au/url?sa $=t \& r c t=j \& q=\& e s r c=s \&$ source $=$ web\&cd $=4 \& c a d=$ rja\&uact $=8$ \&ved=0ahUKEwiAhp S5efMAhVKQiYKHVVJAeAQFggtMAM\&url=http $\% 3 \mathrm{~A} \% 2 \mathrm{~F} \% 2 \mathrm{Fwww}$. eea.europa.eu $\% 2 \mathrm{Fpublications} \% 2 \mathrm{Femep}$-eea-emission-inventory-guidebook-2009\%2Fpart-ageneral-guidance-chapters $\% 2 \mathrm{~F} 5$-uncertainties-tfeip-endorsed-draft.pdf\&usg=AFQjCNGuuwWS8LXbS14pNLmjAMKZNSe4w\&sig2=nrXZSItLfH4QnA25BSnv5g.

Rogo, J. S. (2011). Fiji transport report. New York Retrieved from http://www.un.org/esa/dsd/dsd aofw ni/ni pdfs/NationalReports/fiji/Full text.pdf.

Secratatiat of the Pacific Environment Programme. (2011). Management of solid and hazardous wastes. Paper presented at the Consultation for the GEF-PAS Project, Nadi.

Slezakova, K., Castro, D., Delerue-Matos, C., Alvim-Ferraz, M., Morais, S., \& Pereira, M. (2013). Impact of vehicular traffic emissions on particulate-bound PAHs: Levels and associated health risks. Atmospheric Research, 127, 141-147. doi:10.1016/j.atmosres.2012.06.009

Thaman, R. R., Morrison, R. J. \& Thaman, B. (2003). Wasted islands? Waste and the need for integrated waste management in the Pacific Islands - current status and prospects for reduction and safe disposal. 49.

United Kingdom Government. (2008). Sources of Energy. Retrieved from

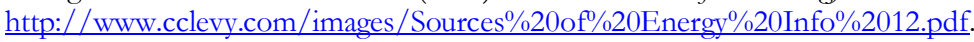

United Nations. (2012). Status of Fuel Quality and Vehicle Emission Standards in Asia-Pacific. Retrieved from http://www.unep.org/transport/pcfv/PDF/Maps Matrices/AP/matrix/AsiaPacific combined March2012.pdf.

United Nations. (2013). Fiji's law dealing with pollution from vebicle exhaust. Retrieved from www.unep.org/transport/pcfv/PDF/Maps Matrices/AP/matrix/AsiaPacific combined March2 012.pdf.

United States Environmental Protection Agency. (1995a). Emission factor documentation for medical waste incineration. Retrieved from https://www3.epa.gov/ttnchie1/ap42/ch02/.

United States Environmental Protection Agency. (1995b). Emission factors for solid waste incineration. Retrieved from https://www3.epa.gov/ttnchie1/ap42/ch02/.

United States Environmental Protection Agency. (2012). Black carbon emissions inventory methods and comparisons. Retrieved from https://www3.epa.gov/blackcarbon/2012report/Appendix2.pdf.

United States Government. (2012). Diesel Fuel. Retrieved from www.epa.gov/OTAQ/fuels/dieselfuels/index.htm.

United States Government. (2016). Fiji. Retrieved from https://www.cia.gov/library/publications/theworld-factbook/.

World Health Organisation. (2006). WHO Air quality guidelines for particulate matter, ozone, nitrogen dioxide and sulfur dioxide. Retrieved from Geneva, Switzerland: http://whqlibdoc.who.int/hq/2006/WHO SDE PHE OEH 06.02 eng.pdf

World Trade Organisation. (2014). Fiji. Retrieved from http://www.wto.org/english/tratop e/tpr e/s213$\underline{03 \text { e.doc. }}$ 
Yao, K. (2008). Collaborative composting project. Launching of the Fiji national solid waste strategy and action plan. Suva City Council and University of the South Pacific. Suva, Fiji.

Yasar, A., Rizwan, H., Bari, A., Kausar, F., \& Khan, M. (2013). A comparison of engine emissions from heavy, medium and light vehicles for CNG, diesel, and gasoline fuels. Pol. J. Environ. Stud., 22(4), 1277-1281.

Zhang, Y., Stedman, D. H., Bishop, G. A., Guenther, P. L., \& Beaton, S. P. (1995). Worldwide on-road vehicle exhaust emissions study by remote sensing. Environ. Sci. Technol(29), 2286-2294. 